\title{
PENGAMBILAN KEPUTUSAN HUTANG PADA USAHA KECIL DAN MENENGAH (UKM) DI PULAU LOMBOK: SUATU PERSPEKTIF BEHAVIORAL FINANCE
}

\author{
Siti Aisyah Hidayati ${ }^{1}$, Embun Suryani ${ }^{2}$, M. Muhdin ${ }^{3}$ \\ ${ }^{1}$ Faculty of Economics and Business, University of Mataram. \\ E-mail: hidayati250573@yahoo.com \\ 2,3 Faculty of Economics and Business, University of Mataram.
}

\begin{tabular}{|c|c|}
\hline ARTICLE INFO & ABSTRACT \\
\hline $\begin{array}{l}\text { Keywords: } \\
\text { Behavioral finance, decision making of debt, } \\
\text { SMEs } \\
\text { How to cite: } \\
\text { Hidayati, SA., Suryani, E., and Muhdin, } \\
\text { M. (2019). Pengambilan Keputusan } \\
\text { Hutang Pada Usaha Kecil Dan Menengah } \\
\text { (Ukm) Di Pulau Lombok: Suatu Perspektif } \\
\text { Behavioral Finance. JMM UNRAM, 8(1), } 1 \\
\text { - } 15 \\
\text { DOI: } \\
\text { 10.29303/jmm.v8i1.404 }\end{array}$ & $\begin{array}{l}\text { The purpose of this study is to find out what factors } \\
\text { determine decision making of debt and what are the most } \\
\text { dominant factors in decision making of debt for SMEs on the } \\
\text { island of Lombok. This research is an explanatory research with } \\
\text { quantitative approach. The population is all SMEs located in } \\
\text { Lombok island. The sample is selected by Non probability } \\
\text { sampling technique with a judgment sampling method where } \\
\text { the SMEs that selected as samples are SMEs in handicraft } \\
\text { industry of pottery and already exporting the products. Of the } \\
\text { existing population, there are } 25 \text { (twenty five) SMEs that can } \\
\text { be sampled. Respondents in this study are managers who also } \\
\text { the owner of the SMEs. Data was collected using questionnaire. } \\
\text { To achieve the research objectives, the data obtained will be } \\
\text { processed according to needs using Factor Analysis. The results } \\
\text { of this study indicate there are three factors that determine } \\
\text { decision making of debt. The most dominant factor in } \\
\text { determining debt decision making for SMEs in Lombok Island } \\
\text { was the Overconfidencefactor. } \\
\text { Tujuan dari penelitian ini adalah untuk } \\
\text { mengetahui faktor-faktor apa yang menentukan } \\
\text { pengambilan keputusan utang dan faktor apa yang } \\
\text { paling dominan dalam pengambilan keputusan utang } \\
\text { untuk UKM di Pulau Lombok. Penelitian ini adalah } \\
\text { penelitian penjelasan dengan pendekatan kuantitatif. } \\
\text { Populasi adalah semua UKM yang berada di Pulau } \\
\text { Lombok. Sampel dipilih dengan teknik Non probability } \\
\text { sampling dengan metode judgment sampling dimana } \\
\text { UKM yang dipilih sebagai sampel adalah UKM dalam } \\
\text { industri kerajinan gerabah dan sudah mengekspor } \\
\text { produk. Dari populasi yang ada, ada } 25 \text { (dua puluh lima) } \\
\text { UKM yang bisa dijadikan sampel. Responden dalam }\end{array}$ \\
\hline
\end{tabular}


penelitian ini adalah manajer yang juga pemilik UKM. Data dikumpulkan menggunakan kuesioner. Untuk mencapai tujuan penelitian, data yang diperoleh akan diproses sesuai dengan kebutuhan menggunakan Analisis Faktor. Hasil dari penelitian ini menunjukkan ada tiga faktor yang menentukan pengambilan keputusan hutang. Faktor yang paling dominan dalam menentukan pengambilan keputusan utang untuk UKM di Pulau Lombok adalah faktor Overconfidence.

Copyright (C) 2019 JMM UNRAM. All rights reserved.

\section{PENDAHULUAN}

Potensi dan peranan Usaha Kecil dan Menengah (UKM) sangat strategis dalam mewujudkan tujuan pembangunan nasional. Pada masa krisis tahun 1997-an, UKM ini tetap memiliki potensi dan peran strategis untuk ikut serta mempercepat perubahan dalam rangka meningkatkan taraf hidup rakyat banyak. UKM juga dapat menciptakan lebih banyak kesempatan kerja dibandingkan investasi yang sama yang pada usaha besar dan memberikan kontribusi pada Produk Domestik Bruto (PDB).

Beberapa karakteristik UKM, yaitu omzet dan tenaga kerjanya masih bersifat fluktuatif, hanya menggunakan teknologi sederhana, dikelola oleh perorangan yang merangkap pemilik sekaligus pengelola perusahaan, serta memanfaatkan tenaga kerja dari keluarga dan kerabat dekatnya (Hastuti, 2003 dan Kuncoro, 2000). Sementara Gibson (2001) menegaskan bahwa pandangan pribadi pemilik secara langsung akan mempengaruhi keputusan bisnis yang dibuat. Hasil penelitian Darmawan (2005) menunjukkan keberhasilan pengembangan usaha dipengaruhi oleh faktor internal maupun eksternal perusahaan. Permasalahan internal yang paling dominan dihadapi adalah keterbatasan sumber pendanaan. Reid (1997) mengungkapkan bahwa sumber pendanaan yang berasal hutang dan injeksi keuangan dari pemilik sama-sama memiliki efek yang signifikan bagi kelanjutan usaha. Menurut Gibson (2007), hubungan antara sumber pendanaan yang berasal dari modal sendiri dan hutang pada mikro dan kecil yang dimiliki perorangan seringkali bersifat kompleks karena aset pemilik digunakan sebagai jaminan hutang, pemilik menghadapi risiko untuk return yang belum pasti.

Keputusan yang lebih didominasi oleh faktor psikologis akan mengarah pada hasil keputusan yang bias karena faktor rasa yang ada pada diri seseorang melebihi pertimbangan faktor rasio. Shefrin (2007) mengidentifikasi berbagai faktor psikologis atau disebutnya fenomena psikologis, yang terbagi ke dalam tiga kategori meliputi bias, heuristic dan framing effect.Bias terdiri dari Excessive Optimism, Overconfidence, Confirmation Bias, Illusion of Control; Heuristic terdiri dari Representativeness, Avaibility, Anchoring and Adjustment, Affect; Framming Effect terdiri dari Loss Aversion dan Aversion to a sure loss Kesepuluh faktor psikologis tersebut digunakan dalam penelitian ini sebagai dasar untuk menentukan faktor-faktor behavioral finance dalam pengambilan keputusan hutang pada Usaha Kecil dan Menengah (UKM) di Pulau Lombok.

Beberapa penelitian behavioral finance selama ini lebih diarahkan untuk menganalisis kaitan faktor psikologis tertentu dengan keputusan keuangan misalnya Investor Overconfidence 
and Volume Trading ( Statman, Thorley and Vorkink, 2006); Sensation Seeking, Overconfidence and Trading Activity (Grinblatt and Keloharju, 2009); Overconfident Managers and External Financing Choice (Ishikawa and Takashashi, 2010); CEO Overconvidence, Corporate Investment Activity, and Performance: Evidence from REITs (Eichholtz and Yonder, 2011); Does Overconfidence Affect Entrepreneurial Investment ? (Henry Friedman, 2007); Behavioural Aspects of Working Capital Managers Ramiah, Zhao, Graham and Mossa,2012 ) The Psychology of Investing (Nofsinger, 2005); Behavioral Corporate Finance: Decision that Create Value( Shefrin, 2007); Behavioral Factors Influencing Individual Investors' Decision Making and Performance (Luong dan Ha, 2011); Persepsi dan Faktor Psikologis dalam Pengambilan Keputusan Hutang (Supramono dan Putlia, 2010), dan Investment DepositoDecision-Making In Bank: A Behavioral Finance Perspective (Hanopia B.L., Surasni N.K.,Hidayati S.A., 2018).

Berdasarkan latar belakang tersebut di atas maka tujuan penelitian ini adalah

1. Untuk mengetahui faktor-faktor yang menentukan pengambilan keputusan hutang pada UKM di Pulau Lombok

2. Untuk Mengetahui Faktor yang paling dominan dalam pengambilan keputusan hutang pada UKM di Pulau Lombok

\section{TINJAUAN PUSTAKA DAN KAJIAN EMPIRIK}

\subsection{Tinjauan Pustaka}

\subsubsection{Pengertian Behavioral Finance}

MenurutDe Bondt, et al. (2008) menyatakan "Behavioral finance is the studyof how psychology impacts financial decisions in households, marketand organizations", yang artinya studi tentang bagaimana psikologi berdampak pada keputusan-keputusan keuangan di dalam rumah tangga, pasar dan organisasi. Sedangkan menurut Pompian (2006) Behavioral Finance, commonly defined as theapplication of psychology to finance. Shefrin's (2005) dalam Forbes (2009) Behavioral finance is the study of how psychological phenomena impact financial behavior. Sedangkan menurut Lintner (1998:7), behaviouralfinance"the study of humans interpret and acton information to make informed investment decisions" artinya, keuangan perilaku merupakan ilmu yang mempelajari bagaimana manusia menginterpretasikan dan bertindak terhadap informasi untuk membuat keputusan dalam berinvestasi. Jadi unsur sikap dan tindakan manusia merupakan faktor penentu dalam berinvestasi. Sehingga Behavioral finance, secara sederhana dapat didefinisikan sebagai aplikasi dari psikologi ke dalam disiplin ilmu keuangan dalam pengambilan keputusan keuangan di dalam rumah tangga, pasar dan organisasi.

\subsubsection{Teori-teori Behavioral Finance}

Ricciardi dan Simon (2000) dalam Gumanti, (2009:9) membagi empat tema utama yang tercakup dalam keuangan perilaku.

a. Overconfidence Theory

Sebagai manusia, tidak dapat disangkal bahwa pengusaha atau manajer memiliki kecenderungan untuk terlalu yakin atas kemampuan dan prediksi untuk berhasil. Kondisi ini merupakan hal yang normal yang sekaligus merupakan cermin dari tingkat keyakinan seseorang untuk mencapai atau mendapatkan sesuatu. 


\section{NATIONALLY ACCREDITED JOURNAL - DECREE NO. 21/E/KPT/2018}

\section{b. Financial Cognitive Dissonance Theory}

Teori ketidakberaturan kognitif keuangan (financial cognitive dissonance) yang dikembangkan oleh Festinger dalam Morton (1993) dalam Gumanti (2009:10), menyatakan bahwa manusia merasakan tekanan internal dan keraguan atau ketakutan manakala dihadapkan pada benturan atau perbedaan keyakinan. Sebagai individu, sebaiknya mencoba untuk mengurangi konflik internal yang ada pada diri (mengurangi dissonance) setidaknya dengan satu dari dua cara berikut, yaitu (1) merubah nilai masa lalu, perasaan atau opini, dan (2) mencoba untuk merasionalisasi pilihan-pilihan.

\section{c. Regret Theory}

Teori penyesalan (regret theory) menyatakan bahwa individual melakukan evaluasi reaksi harapan pada suatu kejadian atau situasi di masa depan. Bell (1982) menggambarkan penyesalan (regret) sebagai emosi yang disebabkan oleh perbandingan pada suatu keluaran tertentu (a given outcome) atau suatu kejadian dengan sesuatu yang tidak jadi dipilih (foregone choice).

\section{d. Prospect Theory}

Teori prospek (prospect theory) berkaitan dengan ide bahwa manusia tidak selalu berperilaku secara rasional. Teori ini beranggapan bahwa ada bias yang melekat dan terus ada yang dimotivasi oleh faktor-faktor psikologi yang mempengaruhi pilihan orang dibawah kondisi ketidakpastian.

\subsection{Kajian Empirik}

Overconfidence adalah salah satu psychological bias dalam pengambilan keputusan yang berkaitan dengan keyakinan yang dimiliki seseorang dengan kemampuan dan pengetahuan yang dimiliki diatas rata-rata. Hal ini dibuktikan oleh penelitian yang dilakukan oleh Statman, Thorley dan Vorkink (2006) yang menyatakan bahwa investor yang overconfidence dapat dijelaskan dengan adanya volume perdagangan yang tinggi. Dengan bias yang ada didalam diri investor, volume perdagangan bervariasi dengan tingkat pengembalian, artinya tidak selalu volume perdagangan tinggi diikuti pengembalian yang tinggi. Bahkan dalam analisis penelitian yang dilakukan oleh Grinblatt dan Keloharju (2009) tidak ditemukan hubungan antara overconfidence dengan perputaran perdagangan. Sedangkan penelitian yang dilakukan oleh Ishikawa dan Takashashi, 2010) menyatakan bahwa manajer pada perusahaan yang terdaftar di Jepang cenderung overconfidence. Hal ini terbukti dengan kecenderungan yang stabil untuk memprediksi laba yang terlalu tinggi dibandingkan dengan yang sebenarnya. Eichholtz dan Yonder (2011) juga membuktikan bahwa keputusan yang overconfidence mempunyai pengaruh negatif terhadap kinerja perusahaan. Penelitian Friedman (2007) menekankan pada keputusan wirausaha, yang menyatakan bahwa overconfidence dalam pengambilan keputusan juga dapat dilihat pada keputusan wirausaha dalam memulai usaha. Mereka tidak menggunakan dana yang bersumber dari luar untuk menjalankan usahanya. Kaitannya dengan modal kerja, Ramiah, et al. (2012) menyatakan bahwa overconfidence merupakan salah satu aspek bias yang apabila digunakan dengan benar dapat meningkatkan efisiensi modal kerja. Artinya tidak selalu overconfidence mempunyai makna negatif.

Illusion of control adalah kecenderungan manusia percaya bahwa mereka dapat mengontrol atau paling tidak mempengaruhi hasil tetapi pada kenyataannya mereka tidak dapat. Dimana pada umumnya seseorang merasa mampu mengendalikan hasil dari keputusan yang diambilnya. Kepercayaan pengusaha dapat memiliki pengaruh terhadap hasil, sehingga investor menaksir terlalu tinggi control yang mereka miliki terhadap hasil 


\section{NATIONALLY ACCREDITED JOURNAL - DECREE NO. 21/E/KPT/2018}

(Nofsinger, 2005). Sedangkan menurut Shefrin (2007) mengemukakan bahwa ketika seorang manajer membuat suatu keputusan, hasil yang diperoleh merupakan kombinasi dari keterampilan yang dipunyai dan keberuntungan.

Availability merupakan bias yang akan mendorong investor untuk membuat keputusan berdasarkan apa yang diingatnya sehingga tidak menyeluruh dalam melakukan analisis untuk membuat keputusan keuangan. Contoh konkrit dari bias ini adalah bagaimana para pekerja akan lebih mempercayai dan membeli saham-saham dari perusahaan tempat mereka bekerja karena berkeyakinan bahwa mereka lebih tahu dan sudah familiar dengan perusahaan tersebut. Efek dari bias ini adalah ketika perusahaan tempat mereka bekerja mengalami hal-hal yang tidak diinginkan maka mereka berpeluang mengalami kerugian. Dalam pengertian bahwa mereka cenderung tidak melakukan diversifikasi dan melakukan analisis yang dangkal sehingga tujuan awal untuk memperoleh keuntungan akan menjadi sia-sia. Bias ini juga tampak dari keputusan investor untuk tidak mau melakukan divesifikasi global dan cenderung mempercayai saham-saham dalam negeri karena familiar dan mudah diingat. Meskipun prinsip fundamental menyebutkan bahwa manajemen portofolio merupakan usaha untuk melakukan optimisasi (Luong dan Ha, 2011).

\section{METODE PENELITIAN}

Penelitian ini merupakan penelitian berbasis pendekatan kuantitatif, dengan jenis penelitian exploratif research untuk mengetahui faktor-faktor apakah yang menentukan pengambilan keputusan hutang dan faktor apa yang paling dominan dalam pengambilan keputusan hutang pada UKM di Pulau Lombok. Penelitian ini dilakukan pada UKM gerabah yang melakukan ekspor di Pulau Lombok.Populasi penelitian adalah semua UKM di Pulau Lombok yang berjumlah unit 64.536 (Dinas Perindustrian dan Perdagangan Prov. NTB, 2016).

Teknik pengambilan sampel dilakukan dengan non probability sampling, yaitu menggunakan judgment sampling yaitu memilih sampel dengan pertimbangan tertentu. Sampel yang diambil adalah UKM yang bergerak pada industri kerajinan gerabah dan sudah melakukan ekspor. Pertimbangan yang digunakan dalam pemilihan UKM tersebut adalah kegiatan memproduksi dan menjual gerabah terutama untuk ekspor ditentukan oleh faktor psikologis yang ada pada diri manajer sekaligus pemilik UKM. Sampel yang dapat diambil dari populasi yang ada adalah 25 UKM yang berada di Pulau Lombok.

Unit analisis penelitian adalah UKM yang bergerak pada usaha gerabah dan sudah melakukan ekspor berjumlah sebanyak 25 UKM yang berada di Pulau Lombok. Responden dalam penelitian ini adalah manajer yang sekaligus pemilik dari tiap-tiap UKM tersebut.

Penelitian ini menggunakan 10 (sepuluh) variabel, yaitu: Excessive Optimism, Overconfidence, Confirmation Bias, Illusion of Control, Representativeness, Avaibility, Anchoring and Adjustment, Affect, Loss Aversion dan Aversion to a sure loss.

Adapun definisi operasional dan Indikator dari masing-masing variabel ditunjukkan dalam Tabel 4.1. 


\section{NATIONALLY ACCREDITED JOURNAL - DECREE NO. 21/E/KPT/2018}

Tabel 4.1

Variabel dan Indikator untuk Menentukan Keputusan Hutang

\begin{tabular}{|c|c|c|}
\hline No. & Variabel & Indikator \\
\hline 1. & $\begin{array}{l}\text { Excessive Optimism: Manajer sekaligus } \\
\text { pemilik UKM cenderung overestimate akan } \\
\text { memperoleh keberhasilan dan underestimate } \\
\text { akan mengalami kegagalan }\end{array}$ & $\begin{array}{l}\text { Mempunyai keyakinan bahwa } \\
\text { prospek perusahaan baik dan } \\
\text { manfaat hutang lebih besar dari } \\
\text { risikonya }\end{array}$ \\
\hline 2 & $\begin{array}{l}\text { Overconfidence: Manajer yakin bahwa } \\
\text { dirinya memiliki kemampuan dan } \\
\text { pengetahuan di atas rata-rata }\end{array}$ & $\begin{array}{l}\text { Mempunyai keyakinan bahwa } \\
\text { mampu melunasi hutang, } \\
\text { menanggung beban bunga } \\
\text { dan melunasi sesuai dengan jangka } \\
\text { waktu pengembalian yang telah } \\
\text { ditetapkan }\end{array}$ \\
\hline 3 & $\begin{array}{l}\text { Confirmation Bias: Manajer cenderung lebih } \\
\text { mempedulikan informasi atau pandangan } \\
\text { yang sejalan dengan pandangannya } \\
\text { daripada yang bertentangan }\end{array}$ & $\begin{array}{l}\text { Pencarian informasi yang } \\
\text { menguatkan pendapat diri sendiri } \\
\text { dan tidak mendengarkan orang lain } \\
\text { yang tidak sepaham }\end{array}$ \\
\hline 4 & $\begin{array}{l}\text { Illusion of Control: Manajer merasa yakin } \\
\text { mampu } 4 \text { mengendalikan } \\
\text { mempengaruhi hasil suatu keputusan } \\
\text { padahal dalam kenyataannya tidak } \\
\text { demikian }\end{array}$ & $\begin{array}{l}\text { Terlibat dan menentukan pilihan } \\
\text { secara aktif dan merasa familiar } \\
\text { terhadap hutang }\end{array}$ \\
\hline 5 & $\begin{array}{l}\text { Representativeness: } \quad \text { Manajer membuat } \\
\text { keputusan berdasarkan kinerja masa lalu }\end{array}$ & $\begin{array}{l}\text { Mempunyai keyakinan bahwa } \\
\text { hutang adalah pilihan terakhir jika } \\
\text { membutuhkan dana }\end{array}$ \\
\hline 6 & $\begin{array}{l}\text { Availability: Manajer lebih mengandalkan } \\
\text { informasi yang tersedia pada saat } \\
\text { pengambilan keputusan }\end{array}$ & $\begin{array}{l}\text { Mendasarkan diri pada informasi } \\
\text { yang telah tersedia dan langsung } \\
\text { menjatuhkan pilihan pada pihak } \\
\text { yang dikenal }\end{array}$ \\
\hline 7 & $\begin{array}{l}\text { Anchoring and Adjustment: Manajer membuat } \\
\text { prediksi dengan referensi dan kemudian } \\
\text { membuat penyesuaian }\end{array}$ & $\begin{array}{l}\text { Pendapatan usahanya ke depan } \\
\text { tidak banyak mengalami perubahan } \\
\text { dan tidak melakukan penyesuaian } \\
\text { kemampuan menanggung hutang }\end{array}$ \\
\hline 8 & $\begin{array}{l}\text { Affect: Manajer dalam membuat keputusan } \\
\text { banyak dipengaruhi oleh intuisi dan } \\
\text { perasaan }\end{array}$ & $\begin{array}{l}\text { Pengambilan keputusan hutang } \\
\text { berdasarkan intuisi dan perasaan }\end{array}$ \\
\hline 9 & $\begin{array}{l}\text { Loss Aversion: Manajer cenderung } \\
\text { menghindari kerugian }\end{array}$ & 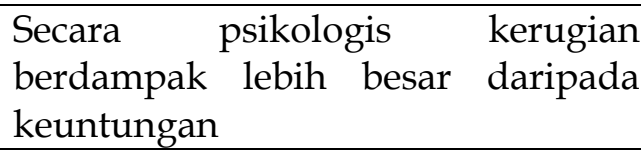 \\
\hline 10 & $\begin{array}{l}\text { Aversion to a sure loss: Manajer yang } \\
\text { mengalami kerugian cenderung menjadi risk } \\
\text { seeker }\end{array}$ & $\begin{array}{l}\text { Mengabaikan kerugian yang sudah } \\
\text { pasti untuk mencapai keuntungan } \\
\text { yang lebih besar }\end{array}$ \\
\hline
\end{tabular}

Sumber : Supramono dan Putlia (2010)

Skala Likert digunakan untuk mengukur variabel. Variabel yang akan diukur dijabarkan menjadi indikator. Pengukuran variabel ini dilakukan dengan skala Likert yang 


\section{NATIONALLY ACCREDITED JOURNAL - DECREE NO. 21/E/KPT/2018}

dituangkan dalam bentuk pilihan jawaban angket, yaitu: a. Sangat tidak setuju (skor 1); b. Tidak Setuju (skor 2); c. Netral (Skor 3); d. Setuju (skor 4); e. Sangat setuju (skor 5).

Jenis data yang digunakan dalam penelitian ini adalah: Data Kualitatif, seperti sikap manajer sekaligus pemilik UKM dalam pengambilan keputusan hutang yang berkaitan dengan Excessive Optimism, Overconfidence, Confirmation Bias, Illusion of Control, Representativeness, Avaibility, Anchoring and Adjustment, Affect, Loss Aversion dan Aversion to a sure loss.. Sumber Data yang digunakan adalah Data primer, yaitu data yang diperoleh langsung dari obyek penelitian, yang berupa jawaban dari pernyataan yang ada di angket. Teknik pengumpulan data yang digunakan dalam penelitian survei ini adalah dengan menggunakan angket.

Selanjutnya data yang dikumpulkan diolah dengan Metode Analisis Faktor yang merupakan teknik untuk mencari faktor - faktor yang mampu menjelaskan hubungan atau korelasi antara berbagai indikator independen yang diobservasi (Widarjono, 2010). 2010) :

Prosedur dalam melakukan analisis faktor terdiri dari tiga langkah yaitu (Widarjono,

1. Menghitung matriks korelasi untuk mengetahui syarat kecukupan bagi data di dalam analisa faktor.

2. Mencari faktor atau ekstraksi faktor yaitu mencari faktor yang mampu menjelaskan korelasi antar indikator yang diteliti.

3. Melakukan rotasi faktor yaitu mencari faktor yang mampu mengoptimalkan korelasi antara indikator independen yang diobservasi.

\section{HASIL PENELITIAN DAN PEMBAHASAN}

\subsection{Hasil Analisis Faktor}

Dalam analisis faktor terdapat beberapa proses tahapan yang dilakukan untuk memperoleh hasil penelitian. Berikut hasil proses analisis faktor yang diperoleh.

\subsubsection{Bartlett's Test of Sphericity dan Kaiser Meyer Olkin}

Bartlett's tes of Spericity (BTS) adalah uji yang digunakan untuk melihat apakah variabel berkorelasi atau tidak dalam sebuah populasi.

Tabel 5.1. KMO and Bartlett's Test (Tahap 1)

\begin{tabular}{|c|c|c|}
\hline $\begin{array}{l}\text { Kaiser-Meyer-O } \\
\text { Adequacy. }\end{array}$ & sure of Sampling & .664 \\
\hline Bartlett's Test of & Approx. Chi-Square & 97.057 \\
\hline Sphericity & Df & 45 \\
\hline & Sig. & .000 \\
\hline
\end{tabular}

Berdasarkan tabel 5.1, KMO dan bartlett's test di atas terlihat angka KMO Measure of sampling Adequacy (MSA) adalah 0.664. Karena nilai 0.664 lebih besar dari 0,05, berarti menunjukkan kecukupan dari sampel. Angka KMO dan Bartlet's test (yang tampak pada nilai chi-square) sebesar 97,057 dengan nilai signifikansi 0.000. hal ini menunjukkan bahwa adanya korelasi antar variabel dan layak untuk proses lebih lanjut. Selanjutnya untuk mengetahui variabel 


\section{NATIONALLY ACCREDITED JOURNAL - DECREE NO. 21/E/KPT/2018}

mana yang dapat diproses lebih lanjut dan mana yang dikeluarkan dapat dilihat pada tabel Anti-image matrices berikut ini.

Tabel 5.2. Nilai MSA Variabel Penelitian (Tahap 1)

\begin{tabular}{|l|c|c|}
\hline \multicolumn{1}{|c|}{ Variabel } & Nilai MSA & Keterangan \\
\hline Excessive Optimism (X1) & $0,646^{\text {(a) }}$ & Tetap \\
\hline Overconfidence (X2) & $0,689^{\text {(a) }}$ & Tetap \\
\hline Confirmation Bias (X3) & 0,717 (a) & Tetap \\
\hline Illusion of Control (X4) & $0,420^{\text {(a) }}$ & Dihilangkan \\
\hline Representativeness (X5) & $0,788^{\text {(a) }}$ & Tetap \\
\hline Avaibility (X6) & $0,642^{\text {(a) }}$ & Tetap \\
\hline Anchoring and Adjustment (X7) & $0,545^{\text {(a) }}$ & Tetap \\
\hline Affect (X8) & 0,657 (a) & Tetap \\
\hline Loss Aversion (X9) & $0,564^{\text {(a) }}$ & Tetap \\
\hline Aversion to sure loss (X10) & 0,789 (a) & Tetap \\
\hline
\end{tabular}

Berdasarkan Tabel 5.2, diperoleh nilai MSA masing-masing variabel lebih besar dari 0,05 kecuali Variabel Illusion of Control (X4) sebesar 0,420 atau lebih kecil dari 0,05, artinya harus dilakukan perhitungan ulang tanpa mengikutsertakan variabel X4.

\section{Tabel 5.3. KMO and Bartlett's Test (Tahap 2)}

\begin{tabular}{|c|c|c|}
\hline \multicolumn{2}{|c|}{$\begin{array}{l}\text { Kaiser-Meyer-Olkin Measure of Sampling } \\
\text { Adequacy. }\end{array}$} & .703 \\
\hline \multirow{3}{*}{$\begin{array}{l}\text { Bartlett's Test of } \\
\text { Sphericity }\end{array}$} & Approx. Chi-Square & 89.680 \\
\hline & Df & \\
\hline & Sig. & \\
\hline
\end{tabular}

Berdasarkan tabel 5.3, KMO dan bartlett's test di atas terlihat angka KMO Measure of sampling Adequacy (MSA) adalah 0.703. Karena nilai 0.703 lebih besar dari 0,05, berarti menunjukkan kecukupan dari sampel. Angka KMO dan Bartlet's test (yang tampak pada nilai chi-square) sebesar 89,680 dengan nilai signifikansi 0.000. hal ini menunjukkan bahwa adanya korelasi antar variabel dan layak untuk proses lebih lanjut. Selanjutnya untuk mengetahui variabel mana yang dapat diproses lebih lanjut dan mana yang dikeluarkan dapat dilihat pada tabel Anti-image matrices berikut ini.

Tabel 5.4. Nilai MSA Variabel Penelitian (Tahap 2)

\begin{tabular}{|l|c|c|}
\hline \multicolumn{1}{|c|}{ Variabel } & Nilai MSA & Keterangan \\
\hline Excessive Optimism (X1) & $0,665^{\text {(a) }}$ & Tetap \\
\hline Overconfidence (X2) & $0,673^{\text {(a) }}$ & Tetap \\
\hline Confirmation Bias (X3) & 0,847 (a) & Tetap \\
\hline Representativeness (X5) & $0,799^{\text {(a) }}$ & Tetap \\
\hline Avaibility (X6) & $0,636^{\text {(a) }}$ & Tetap \\
\hline Anchoring and Adjustment (X7) & $0,525^{\text {(a) }}$ & Tetap \\
\hline Affect (X8) & $0,695^{\text {(a) }}$ & Tetap \\
\hline Loss Aversion (X9) & 0,639 (a) & Tetap \\
\hline Aversion to sure loss (X10) & 0,812 (a) & Tetap \\
\hline
\end{tabular}


Berdasarkan tabel 5.4, diperoleh nilai MSA masing-masing variabel lebih besar dari 0.5 maka semua variabel dapat diproses lebih lanjut atau dengan kata lain apabila nilai MSA lebih besar atau sama dengan 0,5 indikator atau variabel tersebut masih dapat digunakan dalam analisis faktor. Jadi berdasarkan nilai akhir MSA pada tahap kedua ini menunjukkan bahwa diperoleh sembilan variabel yang dapat digunakan pada tahap ekstraksi faktor berikutnya.

Berdasarkan hasil ektraksi faktor yang terlihat pada tabel 5.4, maka diperoleh hasil bahwa sembilan variabel memiliki nilai MSA lebih besar dari 0,5. Artinya variabel yang digunakan tersebut masih temasuk dalam golongan yang memiliki korelasi pada penelitian. Sehingga dari sepuluh variabel yang digunakan yang dapat diproses lebih lanjut ada sembilan variabel seperti yang ditunjukkan oleh tabel 5.4. Dari tahap ekstraksi ini diketahui Confirmation Bias (X3) memiliki nilai MSA yang paling tinggi, yaitu 0,847.

\subsubsection{Ekstraksi Faktor}

Tahapan ini dilakukan dengan melihat tabel communalities dengan nilai extraction di atas 0,5 seperti berikut ini.

Tebel 5.5. Communalities

\begin{tabular}{|l|r|r|}
\hline & \multicolumn{1}{|c|}{ Initial } & Extraction \\
\hline X1 & 1.000 & .777 \\
X2 & 1.000 & .832 \\
X3 & 1.000 & .630 \\
X5 & 1.000 & .777 \\
X6 & 1.000 & .638 \\
X7 & 1.000 & .737 \\
X8 & 1.000 & .780 \\
X9 & 1.000 & .789 \\
X10 & 1.000 & .767 \\
\hline
\end{tabular}

Pada tahap ini dapat diketahui hasil communalities, seperti pada tabel 5.5 yang menunjukkan seberapa besar faktor yang akan terbentuk dapat menjelaskan varian dari suatu indikator (Widarjono, 2010). Misalnya pada variabel X1 diketahui nilai communalities yang diperoleh sebesar 0,777. Artinya sebesar 77,7 persen varians Variabel Excessive Optimism dapat dijelaskan oleh kelompok faktor yang terbentuk. Nilai communalities X2 sebesar 0,832 artinya sebesar 83,2 persen varians Variabel Overconfidence dapat dijelaskan oleh kelompok faktor yang terbentuk. Nilai communalities X3 sebesar 0,630 artinya sebesar 63 persen variansVariabel Confirmation Bias dapat dijelaskan oleh kelompok faktor yang terbentuk. Nilai communalities X5 sebesar 0,777 artinya sebesar 77,7 persen variansVariabel Representativeness dapat dijelaskan oleh kelompok faktor yang terbentuk. Nilai communalities X6 sebesar 0,638 artinya sebesar 63,8 persen variansVariabel Avaibility dapat dijelaskan oleh kelompok faktor yang terbentuk. Nilai communalities X7 sebesar 0,737 artinya sebesar 73,7 persen variansVariabel Anchoring and Adjustment dapat dijelaskan oleh kelompok faktor yang terbentuk. Nilai communalities X8 sebesar 0,780 artinya sebesar 78 persen varians Variabel Affect dapat dijelaskan oleh kelompok faktor yang terbentuk. Nilai communalities X9 sebesar 0,789 artinya sebesar 78,9 persen varians Variabel Loss Aversion dapat dijelaskan oleh kelompok faktor yang terbentuk. Nilai 


\section{NATIONALLY ACCREDITED JOURNAL - DECREE NO. 21/E/KPT/2018}

communalities X10 sebesar 0,767 artinya sebesar 76,7 persen varians Variabel Aversion to sure loss dapat dijelaskan oleh kelompok faktor yang terbentuk.

\subsubsection{Faktor yang Terbentuk dari Nilai Eigenvalue}

Pada analisis faktor ini juga diperoleh tabel hasil total variance explained yang menjelaskan mengenai besarnya varian yang dapat dijelaskan oleh faktor yang terbentuk. Faktor yang terbentuk ini didasarkan pada nilai eigenvalue, yaitu apabila nilai eigenvalue $\geq 1$ maka indikator tersebut diikutsertakan dalam pembentukan faktor, namun apabila nilai eigenvalue $<1$ maka indikator tersebut tidak dapat diikutsertakan dalam pembentukan faktor (Widarjono, 2010). Hasil nilai eigenvalue pada tahap ekstraksi faktor ini dapat dilihat pada tabel 5.6.

Tabel 5.6. Faktor yang Terbentuk dari Nilai Eigenvalue

\begin{tabular}{|c|c|}
\hline Component & Nilai Eigenvalue \\
\hline 1 & 3,510 \\
\hline 2 & 2,106 \\
\hline 3 & 1,111 \\
\hline 4 & 0,744 \\
\hline 5 & 0,416 \\
\hline 6 & 0,362 \\
\hline 7 & 0,334 \\
\hline 8 & 0,282 \\
\hline 9 & 0,135 \\
\hline
\end{tabular}

Pada tabel 5.6 terlihat hasil nilai eigenvalue dari sembilan variebel. Berdasarkan nilai eigenvalue tersebut, maka diketahui terdapat tiga komponen yang memiliki nilai lebih dari 1 $(>1)$. Masing - masing komponen memiliki nilai eigenvalue yaitu pada komponen 1 sebesar 3,510, komponen 2 memiliki nilai eigenvalue sebesar 2,106 dan komponen 3 memiliki nilai eigenvalue sebesar 1,111. Jadi berdasarkan nilai eigenvalue ini terlihat bahwa akan terbentuk tiga kelompok faktor yang berasal dari sembilan variabel.

\subsubsection{Rotasi Faktor}

Pada tahap rotasi faktor kita dapat memperoleh variabel mana saja yang masuk ke dalam kelompok - kelompok faktor yang terbentuk, serta memberikan nama pada setiap kelompok faktor tersebut. Tahap sebelumnya diperoleh sembilan variabel yang dapat digunakan untuk membentuk kelompok faktor. Selanjutnya sembilan variabel tersebut dirotasi dengan menggunakan metode rotasi varimax, sehingga diperoleh tiga kelompok faktor. Hasil dari rotasi dengan metode varimax ini dapat dilihat pada tabel 5.7 
Tabel 5.7. Rotated Component

Matrix

\begin{tabular}{|l|r|r|r|}
\hline & \multicolumn{3}{|c|}{ Component } \\
\cline { 2 - 4 } & \multicolumn{1}{|c|}{1} & \multicolumn{1}{|c|}{2} & \multicolumn{1}{c|}{3} \\
\hline X1 & .830 & .297 & -.003 \\
X2 & .911 & .047 & .034 \\
X3 & .783 & -.033 & .125 \\
X5 & .431 & .754 & .153 \\
X6 & .087 & .771 & .189 \\
X7 & -.446 & .717 & .155 \\
X8 & .214 & .234 & .824 \\
X9 & -.025 & .201 & .865 \\
X10 & .710 & -.142 & .492 \\
\hline
\end{tabular}

Berdasarkan tabel 5.7 diperoleh tiga kelompok faktor, yaitu:

a. Kelompok Faktor 1 terdiri dari: Variabel Excessive Optimism (X1), Variabel Overconfidence (X2), Variabel Confirmation Bias (X3) dan Variabel Aversion to sure loss (X10). Faktor ini diberi nama Faktor Overconfidence.

b. Kelompok Faktor 2 terdiri dari Variabel Representativeness (X5), Variabel Avaibility (X6) dan Variabel Anchoring and Adjustment (X7). Faktor ini diberi nama Faktor Avaibility.

c. Kelompok Faktor 3 terdiri dari Variabel Affect (X8) dan Variabel Loss Aversion (X9). Faktor ini diberi nama Faktor Loss Aversion.

\subsubsection{Faktor Dominan yang Menentukan Pengambilan Keputusan Hutang}

Pada hasil analisis faktor yaitu tabel total variance explained dapat menggambarkan persentase dari masing - masing kelompok faktor yang telah terbentuk. Semakin tinggi nilai extraction sums of squared loadings maka semakin representatif faktor tersebut sebagai wakil sekelompok variabel (Widarjono, 2010). Hasil extraction sums of squared loadings ditunjukkan pada tabel 5.9, terlihat bahwa kelompok faktor yang terbentuk sebanyak tiga faktor. Ketiga faktor tersebut memiliki nilai eigenvalue $>1$.

Tabel 5.8. Hasil Extraction Sums of Squared Loadings Pada Tahap Ekstraksi

\begin{tabular}{|c|r|r|}
\hline \multicolumn{3}{|c|}{ Extraction Sums of Squared Loadings } \\
\hline Total & \% of Variance & Cumulative $\%$ \\
\hline 3.510 & 39.005 & 39.005 \\
\hline 2.106 & 23.398 & 62.403 \\
\hline 1.111 & 12.342 & 74.745 \\
\hline
\end{tabular}

Extraction sums of squared loadings dapat menunjukkan seberapa besar kelompok faktor yang terbentuk menjelaskan varians variabel yang ada. Pada penelitian ini digunakan 
sembilan variabel. Apabila sembilan variabel yang digunakan dalam penelitian dijadikan satu kelompok faktor maka kelompok faktor tersebut mampu menjelaskan varian faktornya sebesar 39,005 persen. Namun apabila sembilan variabel dalam penelitian ini dijadikan tiga kelompok faktor maka ketiga kelompok faktor tersebut mampu menjelaskan varians variabel sebesar 74,745 persen dimana kelompok faktor pertama yaitu kelompok faktor Overconfidence sebesar 39,005 persen, kelompok faktor kedua yaitu kelompok faktor Avaibility sebesar 23,398 persen dan kelompok faktor yang ketiga yaitu kelompok faktor Variabel Loss Aversion sebesar12,342 persenPenelitian ini diperoleh tiga kelompok faktor, maka tiga kelompok faktor ini mampu menjelaskan 74,745 persen total varian dari sembilan variabel yang digunakan dalam penelitian. Angka ini cukup besar karena mampu menjelaskan lebih dari 50 persen varians variabel yang ada. Sehingga berdasarkan hasil extraction sums of squared loadings terlihat bahwa kelompok faktor Overconfidence merupakan kelompok faktor yang paling dominan, karena memiliki persentase varian sebesar 39,005 persen diikuti oleh kelompok faktor Avaibility dan kelompok faktor Loss Aversion. Jadi kelompok faktor Overconfidence yang terdiri dari Variabel Excessive Optimism (X1), Variabel Overconfidence (X2), Variabel Confirmation Bias (X3) dan Variabel Aversion to sure loss (X10) merupakan faktor yang paling dominan menentukan Pengambilan Keputusan Hutang pada UKM yang ada di Pulau Lombok.

\subsection{Pembahasan Hasil Penelitian}

\subsubsection{Faktor-faktor yang Menentukan Pengambilan Keputusan Hutang pada UKM di Pulau Lombok}

Berdasarkan analisa faktor yang dilakukan diperoleh tiga kelompok faktor, yaitu :Kelompok Faktor Pertama terdiri dari Variabel Excessive Optimism (X1), Variabel Overconfidence (X2), Variabel Confirmation Bias (X3) dan Variabel Aversion to sure loss (X10). Faktor ini diberi nama Faktor Overconfidence. Kelompok Faktor Kedua terdiri dari Variabel Representativeness (X5), Variabel Avaibility (X6) dan Variabel Anchoring and Adjustment (X7). Faktor ini diberi nama Faktor Avaibility. Kelompok Faktor Ketiga terdiri dari Variabel Affect (X8) dan Variabel Loss Aversion (X9). Faktor ini diberi nama Faktor Loss Aversion.

Pengambilan keputusan yang dibentuk oleh faktor overconfidence menunjukkan bahwa responden mempunyai keyakinan prospek usaha yang dijalankan baik. Mereka yakin dengan dana yang diperoleh dari hutang akan sangat membantu dalam operasional perusahaan atau dengan kata lain pengelolaan hutang yang dilakukan akan memberikan manfaat yang lebih besar dibandingkan dengan risiko yang akan dialami. Dengan pengelolaan hutang yang baik maka mereka berkeyakinan mampu melunasi hutang, menanggung beban bunga dan mengembalikan sesuai dengan jangka waktu yang ditetapkan. Pengalaman yang sudah dilalui dirasakan sangat membantu untuk menguatkan pendapat sendiri dan merasa tidak perlu mendengar pendapat orang lain yang tidak sepaham. Risiko-risiko yang akan terjadi dianggap "tidak seberapa" dibandingkan dengan keuntungan yang akan diperoleh.

Faktor Avaibility merupakan faktor kedua yang menentukan pengambilan keputusan hutang. Penggunaan hutang sebagai dana operasional merupakan alternatif terakhir bagi manajer sekaligus pemilik UKM sebagai sumber dana eksternal. Informasi untuk mendapatkan dana berupa hutang diambil dari informasi yang sudah tersedia, seperti dana yang dipinjam dari koperasi atau pihak perbankan melalui program Kredit Usaha Rakyat. Responden yang tidak dapat memenuhi persyaratan yang diajukan oleh perbankan melalui 


\section{NATIONALLY ACCREDITED JOURNAL - DECREE NO. 21/E/KPT/2018}

program KUR banyak melakukan kredit pada koperasi yang dirasakan beban bunganya terjangkau dan prosedurnya "tidak serumit" di perbankan. Pendapatan usaha sudah diprediksi relatif stabil sehingga dirasakan tidak perlu menyesuaikan kemampuan dalam menanggung bunga.

Faktor ketiga dalam menentukan pengambilan keputusan hutang adalah faktor Loss Aversion. Instuisi dan perasaan juga menentukan dalam keputusan yang dilakukan oleh manajer dan sekaligus pemilik UKM, termasuk keputusan dalam pengambilan hutang. Berdasarkan pengalaman masa lalu, responden mempunyai kemampuan memprediksi kelangsungan usahanya di masa yang akan datang, sehingga mereka bisa memutuskan apakah dana yang diperoleh melalui hutang menguntungkan atau tidak. Hal ini disebabkan karena secara psikologis kerugian berdampak lebih besar daripada keuntungan.

Pembentukan ketiga faktor ini dilatarbelakangi oleh responden yang sebagian besar berusia produktif, berjenis kelamin laki-laki, dengan tingkat pendidikan menengah keatas dengan jumlah karyawan satu sampai sepuluh orang dan sudah mempunyai pengalaman lebih dari sepuluh tahun. Keputusan pengambilan hutang yang dilakukan oleh manajer sekaligus pemilik UKM di Pulau Lombok didasari oleh keyakinan akan kemampuan untuk membayar semua hutangnya sesuai dengan waktu yang telah ditentukan, informasi berkaitan dengan pihak yang menyediakan dana sudah tersedia dan pengalaman usaha yang lebih dari sepuluh tahun, sehingga manfaat yang diperoleh lebih besar dari risiko yang akan dihadapi. Hal ini sesuai dengan penelitian Supramono dan Putlia (2010) yang menyatakan bahwa keberadaan hutang sebagai sumber pendanaan lebih merupakan stimulator bagi pengusaha untuk memajukan usahanya karena akan memacu untuk bekerja lebih produktif dan disiplin. Selain itu, dengan adanya hutang para pengusaha lebih berhati-hati dalam melakukan pengelolaan keuangan dan merasa lebih dihargai karena dipercaya oleh orang lain.

\subsubsection{Faktor yang paling dominan dalam pengambilan keputusan hutang pada UKM di Pulau Lombok}

Kelompok faktor Overconfidence yang terdiri dari Variabel Excessive Optimism (X1), Variabel Overconfidence (X2), Variabel Confirmation Bias (X3) dan Variabel Aversion to sure loss (X10) merupakan faktor yang paling dominan menentukan Pengambilan Keputusan Hutang pada UKM yang ada di Pulau Lombok. Berdasarkan hal ini bisa dikatakan bahwa keyakinan tentang prospek usaha yang dijalankan akan mempengaruhi psikologis dari para manajer dalam menentukan pengambilan keputusan hutang. Hal ini didasari oleh latar belakang responden yang sebagian besar berusia produktif, berjenis kelamin laki-laki dan berpengalaman benjalankan usahanya lebih dari sepuluh tahun.

\section{KESIMPULAN DAN SARAN}

\subsection{Kesimpulan}

Berdasarkan hasil pembahasan, dapat dikemukakan kesimpulan sebagai berikut:

1. Ada tiga kelompok faktor yang menentukan pengambilan keputusan hutang yaitu

a. Kelompok Faktor Pertama terdiri dari: Variabel Excessive Optimism, Variabel Overconfidence, Variabel Confirmation Bias dan Variabel Aversion to sure loss. Faktor ini diberi nama Faktor Overconfidence. 
b. Kelompok Faktor Kedua terdiri dari Variabel Representativeness, Variabel Avaibilitydan Variabel Anchoring and Adjustment. Faktor ini diberi nama Faktor Avaibility.

c. Kelompok Faktor Ketiga terdiri dari Variabel Affect dan Variabel Loss Aversion. Faktor ini diberi nama Faktor Loss Aversion.

Pembentukan ketiga faktor ini dilatarbelakangi oleh responden yang sebagian besar berusia produktif, berjenis kelamin laki-laki, dengan tingkat pendidikan menengah keatas dengan jumlah karyawan satu sampai sepuluh orang dan sudah mempunyai pengalaman lebih dari sepuluh tahun. Keputusan pengambilan hutang yang dilakukan oleh manajer sekaligus pemilik UKM di Pulau Lombok didasari oleh keyakinan akan kemampuan untuk membayar semua hutangnya sesuai dengan waktu yang telah ditentukan, informasi berkaitan dengan pihak yang menyediakan dana sudah tersedia dan pengalaman usaha yang lebih dari sepuluh tahun, sehingga manfaat yang diperoleh lebih besar dari risiko yang akan dihadapi.

2. Faktor yang paling dominan menentukan pengambilan keputusan hutang pada UKM yang ada di Pulau Lombok adalah kelompok faktor Overconfidence yang terdiri dari Variabel Excessive Optimism, Variabel Overconfidence, Variabel Confirmation Bias dan Variabel Aversion to sure loss. Berdasarkan hal ini bisa dikatakan bahwa keyakinan tentang prospek usaha yang dijalankan akan mempengaruhi psikologis dari para manajer dalam menentukan pengambilan keputusan hutang. Hal ini didasari oleh latar belakang responden yang sebagian besar berusia produktif, berjenis kelamin laki-laki dan berpengalaman menjalankan usahanya lebih dari sepuluh tahun.

\subsection{Saran-saran}

Berdasarkan pada hasil dan kesimpulan penelitian ini, dapat dikemukakan saran-saran yang menjadi rekomendasi pada penelitian berikutnya.

1. Penelitian yang akan datang diharapkan sampel penelitian tidak hanya terbatas pada UKM gerabah yang ekspor saja, karena masih banyak UKM ekspor yang berkembang di masyarakat, seperti UKM kerajinan bambu dan kayu.

2. Penelitian yang akan datang, diharapkan tidak saja pada profit organization tapi juga pada non profit organization, aparat pemerintah dan rumah tangga, sehingga bisa diketahui bagaimana keuangan perilaku pada objek penelitian yang lain.

\section{DAFTAR PUSTAKA}

Bell, D. 1992. Regret in Decision Making Under Uncertainty. Operation Research, Vol. 30, No. 5, pp. 961-981.

Darmawan. 2005. Faktor-Faktor yang Dapat Menentukan Keberhasilan Usaha Industri Mikro, Kecil dan Menengah Sektor Kerajinan di Kotamadya Yogyakarta. Tesis. Pascasarjana Universitas Indonesia.

De Bondt, W. et al. 2008. Behavioral Finance: Quo Vadis ?. Journal of Applied Finance; Fall 2008; 18, 2; ABI/INFORM Research.

Eichholtz and Yonder. 2011. CEO Overconfidence, Corporate Investment Activity, and Performance: Evidence from REITs. Working Paper. Faculty of Business and Economics. Maastricht University Netherlands.

Ferdinand, Augusty. 2011. Metode Penelitian Manajemen. BP. UNDIP. Semarang.

Forbes, William.2009. Behavioural Finance. First Edition. John Wiley \& Sons Ltd. 
Grinblatt and Keloharju. 2009. Sensation Seeking, Overconfidence, and Trading Activity.The Journal of Finance, Vol. LXIV, No. 2, pp. 549-578.

Friedman, Henry. 2007. Does Overconfidence Affect Entrepreneurial Investment ?. Wharton Research Scholars Journal. 5-1-2007

Gibson, B. 2001. Definition of Small Business. Final Report.The University of New Castle. 5, April. Gumanti, Ary Tatang. 2009, Behavior Finance: Suatu Telaah. Usahawan No. 1/Th,XXXVIII.

Hanopia, B.L.; Surasni, N.K and Hidayati, S.A..2018. Investment Deposits Decision-Making In Bank: A Behavioral Finance Perspective.Russian Journal Of Agricultural And Socioeconomic Sciences. 2 (74) February 2018, pp. 115-124

Hastuti. 2003. Upaya Penguatan Usaha Mikro dalam Rangka Peningkatan Ekonomi Perempuan (Sukabumi, Bantul, Kebumen, Padang, Surabaya, Makassar). Jakarta: Lembaga Penelitian Smeru.

Ishikawa, Masaya and Takahashi, Hidetomo. 2010. Overconfident Managers and External FinancingChoice. Review of Behavioral Finance, Vol. 2, pp. 37-58

Kuncoro, M. 2000. Usaha Kecil di Indonesia: Profil, Masalah dan Strategi Pemberdayaan. STIE Yogyakarta.

Lintner, G. 1998. Behavioral Finance: Why Investors Make Bad Decisions.The Planner, 13 (1), 7 8. Vol. 68, No.4.

Luong, Le Phuoe dan Ha, Doan TT. 2011. Behavioral Factors Influencing Individual Investors' Decision Making and Performance. Thesis.Umea School of Business.

Nofsinger, J.R. 2005. The Psychology of Investing. Second Edition. New Jersey: Pearson Prentice Hall, Upper Saddle River.

Pompian, Michael M.2006. Behavioral Finance and Wealth Management. John Wiley \& Sons, Inc.

Ramiah; Zhao; Graham and Moosa. 2012. Behavioural Aspects of Working Capital Managers. School of Economics, Finance and Marketing, RMIT University, Australia.

Reid, G. 2007. Small Firms Actions and Their Survival Probabilities CRIEFF. Department of Economic. University of St. Andrews.

Shefrin, H.2007. Behavioral Corporate Finance: Decision thar Create Value. Mc Grwall-Hill/Irwin.

Supramono; Kaudin; Mahastuti dan Damayanti. 2010. Desain Penelitian Keuangan Berbasis Perilaku. Penerbit: Pusat Studi Keuangan Berbasis Perilaku Fakultas Ekonomi UKSW Salatiga.

Supramono dan Putlia, Nancy. 2010. Persepsi dan Faktor Psikologis dalam Pengambilan Keputusan Hutang. Jurnal Keuangan dan Perbankan, Vol. 14, No. 1 Januari 2010, hal. 2435.

Supranto. (2010). Analisis Multivariat, Arti dan Interpretasi.Jakarta:Rineka Cipta

Statman, Thorley and Vorkink. 2006. Investor Overconfidence and Trading Volume.The Review of Financial Studies, Vol. 19, No. 4, pp.1532-1565.

Weston, J. Fred and Copeland, Thomas E. 1986. Managerial Finance. CBS International Edition. CBS College Publishing. New York.

Wibisono. (2003). Riset Bisnis. PT.Gramedia Pustaka Utama. Jakarta

Widarjono, A. (2010). Analisis Statistika Multivariat Terapan. Yogyakarta:UPP STIE YKPN 